\title{
POTENSI SEDATIF-HIPNOTIK DAUN KAYU GALALA (Erythrina Lithosperma) SEBAGAI KANDIDAT OBAT INSOMNIA
}

\author{
Efraim Samson \\ Wahyudi Abdul Hamid Ridwan \\ Chomsa Dintasari Umi Baszary \\ Jurusan Biologi Fakultas Matematika dan Ilmu Pengetahuan Alam \\ Universitas Pattimura, Ambon \\ E-mail: samsonefraim43@gmail.com
}

\begin{abstract}
The use of drugs from the sedative-hypnotic group to overcome are less popular of insomnia are more and turned to the use of traditional medicines made from plants. The purpose of this study is to determine the potential of kayu galala leaves (Erythrina lithosperma) as a popular of insomnia. A total of 15 male mice to live (Mus musculus) aged \pm 2 months weighing \pm 20 grams, divided into control mice $(K-$ and $K+)$, and mice treated with infusion dose of kayu galala leaves, ie $P 10,3 \mathrm{~mL} / \mathrm{mice} ; P 2$ 0,5 mL/mice; and $P 30,7 \mathrm{~mL} / \mathrm{mice}$. The results showed that kayu galala leaves had a sedative-hypnotic effect. All infusion doses of kayu galala leaves were able to accelerate sedative onset and increase the duration of mice hypnotics, and the most effective dose is $0,7 \mathrm{~mL} /$ mice. The statistical test results showed that awarding of kayu galala leaves infusion had more significant effect in accelerating sedative onset and increasing the duration of mice hypnotics, when compared to the positive control group (+).
\end{abstract}

Keywords: kayu galala, Erythrina lithosperma, sedative-hypnotic, insomnia

\begin{abstract}
ABSTRAK
Penggunaan obat-batan dari golongan sedatif-hipnotik untuk mengatasi masalah insomnia mulai ditinggalkan dan beralih pada penggunaan obat-obatan tradisional berbahan tumbuhan. Tujuan dilakukannya penelitian ini, yakni untuk mengetahui potensi sedatifhipnotik daun kayu galala (Erythrina lithosperma) sebagai kandidat obat insomnia. Sebanyak 15 ekor mencit (Mus musculus) jantan umur \pm 2 bulan dengan berat badan \pm 20 gram, dibagi ke dalam kelompok mencit kontrol (K- dan $\mathrm{K}+$ ), serta kelompok mencit perlakuan dosis infusa daun kayu galala, yakni P1 0,3 mL/ekor; P2 0,5 mL/ekor; dan P3 0,7 $\mathrm{mL} / \mathrm{ekor}$. Hasil penelitian membuktikan bahwa daun kayu galala memiliki efek sedatifhipnotik. Seluruh dosis infusa daun kayu galala mampu mempercepat onset sedatif serta meningkatkan durasi hipnotik mencit, dan yang paling efektif yakni dosis $0,7 \mathrm{~mL} / \mathrm{ekor}$. Hasil uji statistik juga menunjukkan bahwa pemberian infusa daun kayu galala memiliki pengaruh yang lebih signifikan dalam mempercepat onset sedatif serta meningkatkan durasi hipnotik mencit, bila dibanding kelompok kontrol positif $(+)$.
\end{abstract}

Kata Kunci: kayu galala, Erythrina lithosperma, sedatif-hipnotik, insomnia 
Tidur atau suatu keadaan istirahat yang diperlukan oleh manusia untuk tetap menjaga kondisi kesehatan tubuh. Setelah beraktivitas seharian yang melelahkan, tubuh manusia memerlukan tidur yang cukup sebagai bentuk recharge agar kembali pulih, segar, dan berenergi. Selain itu, dengan cukup tidur, otak sebagai pengatur fungsi fisiologis tubuh pun turut beristirahat sehingga dapat mengurangi stres serta membuat tubuh tidak mudah terserang penyakit. Akan tetapi hal ini akan berkebalikan jika tubuh manusia kurang tidur ataupun mengalami gangguan tidur (insomnia). Kondisi tersebut dapat mengakibatkan gangguan hormonal, kelesuan pada tubuh, penurunan konsentrasi, penurunan sistem daya tahan tubuh yang membuat tubuh lebih rentan terserang penyakit (Anggara, 2009; Novindriana, Wijianto, \& Andrie, 2013; Ningsih \& Rahma, 2014; Fitrah, Syakri, \& Harnita, 2018) sehingga dapat berdampak pada penurunan produktivitas hidup.

Insomnia merupakan suatu penyakit gangguan tidur, baik dari segi kualitas juga kuantitas. Penderitanya kesulitan untuk memulai tidur, sulit tertidur pada malam hari, sulit mempertahankan kondisi tertidur atau sering terbangun di malam hari dan sulit tertidur kembali sehingga merasa ketidakcukupan waktu tidur pada saat terbangun (Sutiawan, 2009; Nugroho, Lestari, \& Fitrianingsih, 2016) dan merasa mengantuk serta cepat lelah di siang hari. Insomnia dapat disebabkan karena faktor kejiwaan, yakni adanya stres dan kecemasan yang berlebihan, konsumsi minuman berkafein maupun beralkohol, faktor usia, serta penggunaan obat-obatan antidepresan (Kumalawati, 2012; Nugroho, Lestari, \& Fitrianingsih, 2016; Djalil, Musyarofah, Putra, Genatrika, \& Astuti, 2017). Penyakit ini lebih didominasi oleh orang dewasa dan lansia. Prevalensinya pun cenderung meningkat setiap tahun. Sekitar 20\%-50\% orang dewasa dan lansia mengalami insomnia tiap tahun bahkan $17 \%$ diantaranya mengalami masalah serius (Anggara, 2009; Djalil, Musyarofah, Putra, Genatrika, \& Astuti, 2017).

Beberapa jenis obat dari golongan sedatif-hipnotik biasanya digunakan untuk mengatasi masalah insomnia. Namun, apabila penggunaan jenis obat-obatan tersebut secara terus menerus dan tidak rasional, dapat menyebabkan ketergantungan fisik dan gejala putus obat (Katzung dalam Sari, 2018). Untuk itu, efektifitas dan keamanan obat sedatif-hipnotik perlu menjadi perhatian serius, terutama menyangkut efek samping yang merugikan, yaitu, merasa pusing, hipotensi, distres respirasi, habituasi, toleransi, bahkan adiksi (Rahadian, 2009). Akhir-akhir ini, obat-obatan golongan ini sudah mulai ditinggalkan karena sering menyebabkan ketergantungan, efek toleran, dan menimbulkan gejala withdrawal pada kebanyakan penderita yang menggunakannya. Selain itu, banyak di antara obat-obatan tersebut dilaporkan bersifat toksik bahkan dapat menyebabkan kematian (Amalia, 2009).

Bertolak dari permasalahan tersebut, maka solusi lain yang dicari untuk mengatasi masalah gangguan tidur (insomnia), yakni melalui penggunaan obat-obatan tradisional. Masyarakat pada umumnya menggunakan obat tradisional berbahan tumbuh-tumbuhan berdasarkan pengalaman secara turun temurun, dan masih berlangsung sampai sekarang. Kepercayaan masyarakat terhadap penggunaan obat tradisional meningkat, oleh karena berbahan alami dan dinilai lebih aman serta tidak menimbulkan efek samping (Jannah, 2009). Hal ini juga direkomendasikan oleh WHO untuk menggunakan obat tradisional dalam pemeliharaan kesehatan masyarakat, pencegahan, dan pengobatan penyakit (Dewi, 2009). Beberapa hasil penelitian menunjukkan, bahwa kandungan zat aktif yang terkandung dalam tumbuhan ternyata juga memiliki potensi sedatif-hipnotik yang tidak kalah efektif dengan obat-obat kimia. Menurut Purnomo, Darsono, \& Santosa (2004), pemberian infusa buah kayu ules (Helicteres isora L.) pada mencit dengan dosis $5 \mathrm{DM}$, memiliki efek memulai tidur yang lebih cepat bahkan setara dengan diazepam. Selanjutnya menurut Marfu'ah, Sudarso, \& 
Diniatik. (2013), pemberian ekstrak etanol daun ubi jalar (Ipomoea batatas L.) pada mencit dengan dosis $382 \mathrm{mg} / \mathrm{Kg} \mathrm{BB}$ dan $573 \mathrm{mg} / \mathrm{Kg} \mathrm{BB}$, memberikan efek sedatif yang sama dengan kontrol positif fenobarbital dosis 54,6 mg/KgBB. Begitu pula dengan Nugroho, Lestari, \& Fitrianingsih. (2016), melalui hasil penelitiannya menunjukkan, bahwa pemberian ekstrak etanol daun afrika pada dosis $100 \mathrm{mg} / \mathrm{kg}$ BB dengan metode sleeping time, memberikan efek sedatif-hipnotik yang lebih baik dengan rata-rata onset 27,83 detik dibandingkan kontrol $(\mathrm{P}=0,000)$. Selain itu, Novindriana, Wijianto, \& Andrie. (2013), juga melaporkan bahwa ekstrak etanol daun kratom (Mitragyna speciosa Korth) memiliki efek sedatif pada mencit jantan galur BALB/c, dengan dosis efektif ekstrak etanol daun kratom adalah dosis 48,57 mg/20g/ BB. Efek sedatif yang dihasilkan ekstrak etanol daun kratom memiliki potensi yang lebih besar jika dibandingkan dengan diazepam sebagai kontrol (+).

Dadap Serep (Erythrina lithosperma) merupakan salah satu jenis tumbuhan yang memiliki banyak khasiat sebagai obat tradisional, namun tidak banyak masyarakat Indonesia yang mengetahuinya. Tumbuhan ini berkhasiat sebagai obat untuk berbagai penyakit, diantaranya: demam nifas pada wanita, mencegah keguguran, luka bagian dalam, sakit perut, pelancar ASI, serta kulit batangnya digunakan sebagai pengencer dahak (Revisika, 2011). Hasil uji fitokimia menunjukkan adanya kandungan alkaloid, flavonoid, saponin, tannin, dan polifenol, yang terkandung dalam tumbuhan ini. Adanya kandungan zat-zat inilah yang diduga membuat tumbuhan tersebut dapat digunakan sebagai antimalaria, antipiretik, antimikroba, dan antiinflamasi (Desianti dalam Kholidha, Suherman, \& Hartati, 2016; Rahman, Firmansyah, \& Setyabudi, 2018). Selain itu, kandungan saponin, flavonoida, dan tanin, dilaporkan dapat menyebabkan efek sedatif (Takahashi, de Lima, \& Morato, 1986; Hanrahan, Chebib, \& Johnston, 2011; Hidayati, 2013; Sari, 2018). Di Maluku, tumbuhan ini dikenal dengan nama kayu galala. Berdasarkan pengalaman empiris, ternyata daunnya juga digunakan sebagai sayuran sekaligus dapat mengobati gangguan tidur atau insomnia. Hal inilah yang melatarbelakangi penulis untuk melakukan kajian secara ilmiah guna mengetahui potensi sedatif-hipnotik daun kayu galala.

\section{METODE}

\section{Rancangan Penelitian}

Penelitian ini merupakan penelitian eksperimen laboratorik yang dilakukan April-Mei 2019 pada Laboratorium Zoologi, Jurusan Biologi, Fakultas Matematika dan IImu Pengetahuan Alam, Universitas Pattimura, Ambon. Rancangan penelitian menggunakan Rancangan Acak Lengkap (RAL) dengan 3 kali pengulangan. Dalam penelitian ini, menggunakan 15 ekor mencit (Mus musculus) jantan umur \pm 2 bulan dengan berat badan \pm 20 gram, yang dibagi ke dalam kelompok mencit kontrol dan kelompok mencit perlakuan dosis infusa daun kayu galala. Kelompok mencit kontrol terdiri atas kelompok kontrol negatif (-), yakni kelompok yang hanya diberi aquadest dan kelompok kontrol positif (+), yakni kelompok yang diberi CTM (Chlorpheniramine maleate) dosis 0,3 $\mathrm{mL} / \mathrm{g} /$ mencit. Sedangkan kelompok mencit perlakuan dosis infusa daun kayu galala terdiri atas kelompok P1, yakni mencit yang diberi infusa daun kayu galala dengan dosis $0,3 \mathrm{~mL} / \mathrm{g} / \mathrm{mencit}$; kelompok P2, yakni mencit yang diberi infusa daun kayu galala dengan dosis $0,5 \mathrm{~mL} / \mathrm{g} / \mathrm{mencit}$; dan kelompok P3, yakni mencit yang diberi infusa daun kayu galala dengan dosis $0,7 \mathrm{~mL} / \mathrm{g} / \mathrm{mencit}$.

Pemberian CTM maupun infusa daun kayu galala, dilakukan per oral. Masing-masing kelompok terdiri atas 3 ekor mencit dan semua mencit tersebut diaklimatisasi terlebih dahulu selama satu minggu serta tetap diberi pakan dan minum standar. Pemilihan obat CTM sebagai kontrol (+) dalam penelitian ini, didasari oleh pertimbangan obat ini harganya relatif murah dan mudah dijangkau oleh masyarakat walau tanpa resep dokter serta sering digunakan di kala mengalami gangguan tidur. 


\section{Sumber Data}

Data yang dikumpulkan dalam penelitian ini adalah data primer, dari hasil pengukuran:

1. Onset sedatif atau waktu timbulnya efek sedasi pasca pemberian infusa daun kayu galala;

2. Durasi hipnotik atau waktu tertidur hingga terbangun.

\section{Teknik Pengumpulan Data}

Efek sedatif yang ditimbulkan pada kelompok mencit kontrol positif (+), P1, P2, dan P3, diamati secara kuantitatif dan kualitatif. Pengamatan kuantitatif dilakukan melalui perhitungan onset sedatif, yakni lama waktu timbulnya efek sedatif pada mencit atau waktu yang diperlukan mencit untuk mulai tertidur pasca pemberian CTM dosis 0,3 mL/ekor pada mencit kelompok kontrol positif $(+)$ dan infusa daun kayu galala per oral pada masing-masing kelompok perlakuan (P1, P2, dan P3). Gejala efek sedatif yang ditimbulkan pasca pemberian CTM maupun infusa daun kayu galala, diamati secara kualitatif melalui aktivitas motorik yang ditunjukan oleh mencit. Aktivitas motorik mencit yang diamati dan dijadikan sebagai tanda munculnya efek sedatif, yakni melemahnya gerak aktif mencit atau mencit tidak lagi berpindah-pindah tempat dan diam pada satu sisi dalam area kandang, mulai kehilangan kepekaan terhadap lingkungan sekitarnya serta kondisi kelopak mata yang perlahan-lahan mulai menutup.

Kemudian untuk efek hipnotik yang ditimbulkan pada kelompok mencit kontrol positif (+), P1, P2, dan P3, juga diamati secara kuantitatif dan kualitatif. Pengamatan kuantitatif dilakukan melalui perhitungan durasi hipnotik atau tidur, yakni lama waktu mencit tertidur hingga mencit terbangun dengan kondisi aktif dan lincah bergerak kembali, atau dengan kata lain, durasi hipnotik dihitung sejak mencit mulai tertidur hingga terbangun. Kriteria mencit tertidur hingga terbangun, didasarkan pada pengamatan kualitatif melalui aktivitas motoriknya. Dalam kondisi hipnotik, mencit tidak lagi menunjukkan pergerakan; diam pada satu sisi dalam area kandang dengan posisi tubuh agak meringkuk, dan secara penuh kehilangan kepekaan terhadap lingkungan sekitarnya serta kondisi kelopak mata yang tertutup rapat. Sedangkan ketika terbangun, mencit terlihat aktif dan lincah bergerak kembali.

\section{Analisa Data}

Data primer yang telah diperoleh dalam penlitian ini dilanjutkan dengan uji statistik menggunakan uji One Way ANOVA dibantu dengan program SPSS.

\section{HASIL DAN PEMBAHASAN}

Dalam penelitian ini, pemberian infusa daun kayu galala dengan dosis bertingkat terhadap kelompok mencit P1, P2, dan P3, dimaksudkan agar dapat mempercepat onset sedatif atau waktu timbulnya efek sedasi pasca pemberian infusa daun kayu galala dan meningkatkan durasi hipnotik atau waktu tidur mencit hingga terbangun secara signifikan.

\section{Efek Sedatif}

Hasil perhitungan onset sedatif mencit pasca pemberian infusa daun kayu galala, disajikan dalam data Tabel 1. Sedangkan hasil analisis uji Anova One Way dan analisis lanjutan Post Hoc Test dengan uji LSD terhadap rata-rata onset sedatif, disajikan data Tabel 2. 
Tabel 1. Onset Sedatif Mencit

\begin{tabular}{cc}
\hline Kelompok Mencit & $\begin{array}{c}\text { Onset Sedatif } \\
\text { (Menit) }\end{array}$ \\
\hline Kontrol negatif (-) & $0,00 \pm 0,00^{\mathrm{a}}$ \\
Kontrol positif (+) & $77,00 \pm 3,00^{\mathrm{b}}$ \\
Dosis $0,3 \mathrm{~mL} / \mathrm{ekor}^{(\mathrm{P} 1)}$ & $55,00 \pm 1,00^{\mathrm{c}}$ \\
Dosis $0,5 \mathrm{~mL} / \mathrm{ekor}(\mathrm{P} 2)$ & $40,00 \pm 1,00^{\mathrm{d}}$ \\
Dosis $0,7 \mathrm{~mL} / \mathrm{ekor}(\mathrm{P} 3)$ & $36,00 \pm 1,00^{\mathrm{e}}$ \\
\hline
\end{tabular}

Tabel 2. Hasil Uji Lanjut LSD terhadap Rata-Rata Onset Sedatif

\begin{tabular}{|c|c|c|c|c|c|c|}
\hline \multirow{2}{*}{ (I) Perlakuan } & \multirow{2}{*}{ (J) Perlakuan } & \multirow{2}{*}{$\begin{array}{c}\text { Mean } \\
\text { Difference (I-J) }\end{array}$} & \multirow{2}{*}{ Std. Error } & \multirow{2}{*}{ Sig. } & \multicolumn{2}{|c|}{$95 \%$ Confidence Interval } \\
\hline & & & & & Lower Bound & Upper Bound \\
\hline \multirow{4}{*}{ Kontrol negatif (-) } & Kontrol (+) & $-77,000^{*}$ & 1,265 & 0,000 & $-79,82$ & $-74,18$ \\
\hline & Dosis $0,3 \mathrm{~mL}$ & $-55,000^{*}$ & 1,265 & 0,000 & $-57,82$ & $-52,18$ \\
\hline & Dosis $0,5 \mathrm{~mL}$ & $-40,000^{*}$ & 1,265 & 0,000 & $-42,82$ & $-37,18$ \\
\hline & Dosis $0,7 \mathrm{~mL}$ & $-36,000^{\star}$ & 1,265 & 0,000 & $-38,82$ & $-33,18$ \\
\hline \multirow{4}{*}{ Kontrol positif $(+)$} & Kontrol (-) & $77,000^{*}$ & 1,265 & 0,000 & 74,18 & 79,82 \\
\hline & Dosis $0,3 \mathrm{~mL}$ & $22,000^{*}$ & 1,265 & 0,000 & 19,18 & 24,82 \\
\hline & Dosis $0,5 \mathrm{~mL}$ & $37,000^{*}$ & 1,265 & 0,000 & 34,18 & 39,82 \\
\hline & Dosis $0,7 \mathrm{~mL}$ & $41,000^{*}$ & 1,265 & 0,000 & 38,18 & 43,82 \\
\hline \multirow{4}{*}{ Dosis $0,3 \mathrm{~mL}$} & Kontrol (-) & $55,000^{*}$ & 1,265 & 0,000 & 52,18 & 57,82 \\
\hline & Kontrol (+) & $-22,000^{*}$ & 1,265 & 0,000 & $-24,82$ & $-19,18$ \\
\hline & Dosis $0,5 \mathrm{~mL}$ & $15,000^{*}$ & 1,265 & 0,000 & 12,18 & 17,82 \\
\hline & Dosis $0,7 \mathrm{~mL}$ & $19,000^{*}$ & 1,265 & 0,000 & 16,18 & 21,82 \\
\hline \multirow{4}{*}{ Dosis $0,5 \mathrm{~mL}$} & Kontrol (-) & $40,000^{*}$ & 1,265 & 0,000 & 37,18 & 42,82 \\
\hline & Kontrol (+) & $-37,000^{*}$ & 1,265 & 0,000 & $-39,82$ & $-34,18$ \\
\hline & Dosis $0,3 \mathrm{~mL}$ & $-15,000^{*}$ & 1,265 & 0,000 & $-17,82$ & $-12,18$ \\
\hline & Dosis $0,7 \mathrm{~mL}$ & $4,000^{*}$ & 1,265 & 0,010 & 1,18 & 6,82 \\
\hline \multirow{4}{*}{ Dosis 0,7 mL } & Kontrol (-) & $36,000^{*}$ & 1,265 & 0,000 & 33,18 & 38,82 \\
\hline & Kontrol (+) & $-41,000^{*}$ & 1,265 & 0,000 & $-43,82$ & $-38,18$ \\
\hline & Dosis $0,3 \mathrm{~mL}$ & $-19,000^{*}$ & 1,265 & 0,000 & $-21,82$ & $-16,18$ \\
\hline & Dosis $0,5 \mathrm{~mL}$ & $-4,000^{*}$ & 1,265 & 0,010 & $-6,82$ & $-1,18$ \\
\hline
\end{tabular}

Ket: Dependent Variable: Onset Sedatif;

Based on observed means;

(*) The mean difference is significant at the 0,05 level. 
Data Tabel 1 menunjukkan, bahwa pada kelompok mencit kontrol negatif (-) atau tanpa pemberian CTM maupun infusa daun kayu galala, tidak menunjukkan adanya efek sedatif-hipnotik pada saat penelitian dilakukan. Mencit pada kelompok ini tetap terlihat aktif bergerak sehingga onset sedatif hipnotik tidak dihitung atau dianggap 0 menit. Kemudian, pada kelompok mencit kontrol positif (+) yang diberikan CTM, menunjukkan adanya efek sedatif namun rata-rata onset sedatifnya lebih lama, yakni 77,00 menit bila dibanding kelompok mencit P1, P2, dan P3. Pada kelompok mencit yang diberikan infusa daun kayu galala, yakni dosis 0,3 mL/ekor (P1), 0,5 mL/ekor (P2), dan 0.7 $\mathrm{mL} /$ ekor (P3), mampu mencapai efek sedatif serta menunjukkan adanya peningkatan rata-rata onset sedatif dengan respon berbeda-beda, yakni: P1 (55,00 menit); P2 (40,00 menit); dan P3 (36,00 menit). Rata-rata onset sedatif tersebut lebih cepat bila dibanding dengan rata-rata onset sedatif pada kelompok mencit kontrol positif (+). Hasil analisis uji Anova One Way dan analisis lanjutan Post Hoc Test dengan uji LSD terhadap rata-rata onset sedatif (Tabel 2) pada masing-masing kelompok mencit juga menunjukkan bahwa terdapat perbedaan yang bermakna, baik antara kelompok kontrol dengan kelompok perlakuan maupun antar sesama kelompok perlakuan, dengan nilai signifikansi $p<0,05$.

Namun, di antara ketiga kelompok perlakuan tersebut, kelompok P3 memiliki rata-rata onset sedatif yang lebih cepat, yakni 36,00 menit. Hal ini berarti, rata-rata waktu yang dibutuhkan untuk mencapai efek sedatif pasca pemberian infusa daun kayu galala pada kelompok mencit P3 adalah 36.00 menit. Pada menit ke 36.00 , kondisi mencit pada kelompok P3 mulai terlihat melemah gerak aktifnya dan tidak lagi berpindah-pindah tempat atau diam pada satu sisi dalam area kandang serta mulai kehilangan kepekaan terhadap lingkungan sekitarnya dengan kondisi kelopak mata yang perlahan-lahan mulai menutup.

\section{Efek Hipnotik}

Setelah mencit pada kelompok kontrol positif (+) dan kelompok perlakuan (P1, P2, dan P3) mencapai efek sedatif, selanjutnya dilakukan perhitungan durasi hipnotik mencit. Hasil perhitungan durasi hipnotik mencit pada penelitian ini, disajikan dalam data Tabel 3.

Tabel 3. Durasi Hipnotik Mencit

\begin{tabular}{cc} 
Kelompok Mencit & $\begin{array}{c}\text { Durasi Hipnotik } \\
\text { (Menit) }\end{array}$ \\
\hline Kontrol negatif (-) & $0,00 \pm 0,00^{\mathrm{a}}$ \\
Kontrol positif $(+)$ & $5,67 \pm 0,57^{\mathrm{b}}$ \\
Dosis $0,3 \mathrm{~mL} / \mathrm{ekor}(\mathrm{P} 1)$ & $8,33 \pm 0,15^{\mathrm{c}}$ \\
Dosis $0,5 \mathrm{~mL} /$ ekor (P2) & $11,00 \pm 0,10^{\mathrm{d}}$ \\
Dosis $0,7 \mathrm{~mL} / \mathrm{ekor}(\mathrm{P} 3)$ & $17,67 \pm 0,10^{\mathrm{e}}$ \\
\hline
\end{tabular}

Sedangkan hasil analisis uji Anova One Way dan analisis lanjutan Post Hoc Test dengan uji LSD terhadap rata-rata durasi hipnotik, disajikan dalam data Tabel 4. 
Tabel 4. Hasil Uji Lanjut LSD terhadap Rata-Rata Durasi Hipnotik

\begin{tabular}{|c|c|c|c|c|c|c|}
\hline \multirow{2}{*}{ (I) Perlakuan } & \multirow{2}{*}{ (J) Perlakuan } & \multirow{2}{*}{$\begin{array}{c}\text { Mean } \\
\text { Difference (I-J) }\end{array}$} & \multirow{2}{*}{ Std. Error } & \multirow{2}{*}{ Sig. } & \multicolumn{2}{|c|}{ 95\% Confidence Interval } \\
\hline & & & & & Lower Bound & Upper Bound \\
\hline \multirow{4}{*}{ Kontrol negatif (-) } & Kontrol (+) & $-5,667^{*}$ & 1,155 & 0,001 & $-8,24$ & $-3,09$ \\
\hline & Dosis $0,3 \mathrm{~mL}$ & $-8,333^{*}$ & 1,155 & 0,000 & $-10,91$ & $-5,76$ \\
\hline & Dosis $0,5 \mathrm{~mL}$ & $-11,000^{*}$ & 1,155 & 0,000 & $-13,57$ & $-8,43$ \\
\hline & Dosis $0,7 \mathrm{~mL}$ & $-17,667^{*}$ & 1,155 & 0,000 & $-20,24$ & $-15,09$ \\
\hline \multirow{4}{*}{ Kontrol positif (+) } & Kontrol (-) & $5,667^{*}$ & 1,155 & 0,001 & 3,09 & 8,24 \\
\hline & Dosis $0,3 \mathrm{~mL}$ & $-2,667^{*}$ & 1,155 & 0,044 & $-5,24$ & $-0,09$ \\
\hline & Dosis $0,5 \mathrm{~mL}$ & $-5,333^{*}$ & 1,155 & 0,001 & $-7,91$ & $-2,76$ \\
\hline & Dosis $0,7 \mathrm{~mL}$ & $-12,000^{*}$ & 1,155 & 0,000 & $-14,57$ & $-9,43$ \\
\hline \multirow{4}{*}{ Dosis $0,3 \mathrm{~mL}$} & Kontrol (-) & $8,333^{*}$ & 1,155 & 0,000 & 5,76 & 10,91 \\
\hline & Kontrol (+) & $2,667^{*}$ & 1,155 & 0,044 & 0,09 & 5,24 \\
\hline & Dosis $0,5 \mathrm{~mL}$ & $-2,667^{*}$ & 1,155 & 0,044 & $-5,24$ & $-0,09$ \\
\hline & Dosis $0,7 \mathrm{~mL}$ & $-9,333^{*}$ & 1,155 & 0,000 & $-11,91$ & $-6,76$ \\
\hline \multirow{4}{*}{ Dosis $0,5 \mathrm{~mL}$} & Kontrol (-) & $11,000^{*}$ & 1,155 & 0,000 & 8,43 & 13,57 \\
\hline & Kontrol (+) & $5,333^{*}$ & 1,155 & 0,001 & 2,76 & 7,91 \\
\hline & Dosis $0,3 \mathrm{~mL}$ & $2,667^{*}$ & 1,155 & 0,044 & 0,09 & 5,24 \\
\hline & Dosis $0,7 \mathrm{~mL}$ & $-6,667^{*}$ & 1,155 & 0,000 & $-9,24$ & $-4,09$ \\
\hline \multirow{4}{*}{ Dosis $0,7 \mathrm{~mL}$} & Kontrol (-) & $17,667^{\star}$ & 1,155 & 0,000 & 15,09 & 20,24 \\
\hline & Kontrol (+) & $12,000^{*}$ & 1,155 & 0,000 & 9,43 & 14,57 \\
\hline & Dosis $0,3 \mathrm{~mL}$ & $9,333^{*}$ & 1,155 & 0,000 & 6,76 & 11,91 \\
\hline & Dosis $0,5 \mathrm{~mL}$ & $6,667^{*}$ & 1,155 & 0,000 & 4,09 & 9,24 \\
\hline
\end{tabular}

Ket: Dependent Variable: Durasi Hipnotik;

Based on observed means;

${ }^{*}$ ) The mean difference is significant at the 0,05 level.

Data Tabel 3 menunjukkan, bahwa pada kelompok mencit kontrol negatif (-) atau tanpa pemberian CTM maupun infusa daun kayu galala, tidak menyebabkan mencit tertidur pada saat penelitian dilakukan. Mencit pada kelompok ini tetap terlihat aktif bergerak sehingga durasi hipnotik tidak dihitung atau dianggap 0 menit. Kemudian, pada kelompok mencit kontrol positif (+) yang diberikan CTM, menunjukkan adanya efek hipnotik namun rata-rata durasi hipnotiknya lebih cepat, yakni 5.67 menit bila dibanding kelompok mencit P1, P2, dan P3. Pada kelompok mencit yang diberi infusa daun kayu galala, yakni dosis $0,3 \mathrm{~mL} / \mathrm{ekor}(\mathrm{P} 1), 0,5 \mathrm{~mL} / \mathrm{ekor}(\mathrm{P} 2)$, dan $0.7 \mathrm{~mL} / \mathrm{ekor}(\mathrm{P} 3)$, mampu mencapai efek hipnotik serta menunjukkan adanya peningkatan rata-rata durasi hipnotik dengan respon yang berbeda-beda, yakni : dosis $0,3 \mathrm{~mL} / \mathrm{ekor}$ (8.33 menit); dosis $0,5 \mathrm{~mL} / \mathrm{ekor}$ (11.00 menit); dan dosis $0,7 \mathrm{~mL} / \mathrm{ekor}$ (17.67 menit). Rata-rata durasi hipnotik tersebut lebih lama bila 
dibanding dengan rata-rata durasi hipnotik pada kelompok mencit kontrol positif (+). Hasil uji statistik pun juga menunjukkan adanya beda nyata yang signifikan antara kelompok kontrol positif $(+), P 1$, P2, dan P3. Hasil analisis uji Anova One Way dan analisis lanjutan Post Hoc Test dengan uji LSD terhadap rata-rata durasi hipnotik (Tabel 4) pada masing-masing kelompok mencit, juga menunjukkan bahwa terdapat perbedaan yang bermakna, baik antara kelompok kontrol dengan kelompok perlakuan maupun antar sesama kelompok perlakuan, dengan nilai signifikansi $p<0,05$.

Namun, di antara ketiga kelompok perlakuan tersebut, kelompok P3 memiliki rata-rata durasi hipnotik yang lebih lama, yakni 17.67 menit. Hal ini berarti, mencit pada kelompok P3 berada dalam kondisi tertidur selama 17.67 menit hingga kembali terbangun. Selama berada dalam kondisi tertidur, mencit pada kelompok P3 terlihat tidak menunjukkan pergerakan, diam pada satu sisi dalam area kandang dengan posisi tubuh agak meringkuk, dan secara penuh kehilangan kepekaan terhadap lingkungan sekitarnya serta kondisi kelopak mata yang tertutup rapat. Setelah durasi 17.67 menit atau efek hipnotiknya hilang, maka mencit pada kelompok tersebut terbangun dengan kondisi aktif dan lincah bergerak kembali.

Hasil penelitian ini membuktikan, bahwa daun kayu galala memiliki efek sedatif-hipnotik yang mampu mempercepat onset sedatif serta meningkatkan durasi hipnotik. Dikatakan demikian, karena melalui pemberian infusa daun kayu galala pada kelompok mencit P1, P2, dan P3, mampu mempercepat onset sedatif, bahkan onsetnya lebih cepat bila dibanding dengan kelompok mencit kontrol positif (+). Selain itu, pemberian infusa daun kayu galala pada kelompok mencit P1, P2, dan P3, juga mampu meningkatkan durasi hipnotik atau waktu mempertahankan keadaan tidur mencit, dengan durasi yang lebih lama bila dibanding dengan kelompok kontrol positif (+). Secara statistik pun juga menunjukkan bahwa pemberian infusa daun kayu galala pada kelompok mencit perlakuan (P1, P2, P3) memiliki pengaruh yang lebih signifikan dalam mempercepat onset sedatif dan meningkatkan durasi hipnotik bila dibanding dengan kelompok kontrol positif $(+)$. Di antara ketiga dosis infusa tersebut, yang dinilai paling efektif adalah dosis $0,7 \mathrm{~mL} / \mathrm{ekor}$ karena memiliki rata-rata onset sedatif yang tercepat dan memiliki rata-rata durasi hipnotik terlama bila dibanding kelompok mencit lainnya.

Efek sedatif-hipnotik yang ditimbulkan melalui pemberian infusa daun kayu galala diduga merupakan efek dari senyawa yang terkandung di dalamnya yang dapat menekan sistem saraf pusat. Sebagaimana telah disampaikan sebelumnya bahwa hasil uji fitokimia dari berbagai bagian tanaman galala ini, dilaporkan memiliki kandungan alkaloid, flavonoid, saponin, tannin, dan polifenol (Desianti dalam Kholidha, et al., 2016; Rahman, et al., 2018). Kandungan senyawa tersebut telah dilaporkan dapat menyebabkan efek sedatif (Takahashi, et al., 1986; Hanrahan, et al., 2011; Sari, 2018). Selain itu, Harborne dalam Maya (2008), juga memaparkan bahwa ada senyawa flavonoid yang beraktivitas sebagai hipnotik-sedatif, seperti: adenosine, apigenin, cinnamaldehyde. Begitu pula dengan Cordell dalam Maya (2008), yang juga memaparkan bahwa ada senyawa alkaloid yang menimbulkan anticemas, seperti: muscimol, reserpine, xylopine. Hal ini pun sesuai dengan hasil-hasil penelitian sebelumnya, antara lain: menurut Mun'im \& Hanani dalam Novindriana, et al., (2013), melaporkan bahwa krisin (flavonoid) dalam herba Passiflora incarnata L. pada percobaan secara in vitro dapat berikatan dengan reseptor benzodiazepine, mengurangi aktivitas lokomotorik dan meningkatkan efek hipnosis pada hewan yang diinduksi dengan pentobarbitalum. Selanjutnya, Hidayati (2013), melaporkan bahwa ekstrak $n$-heksan daun kratom (Mitragyna speciosa Korth) yang mengandung golongan metabolit sekunder alkaloid, glikosida, steroid, dan flavonoid, memiliki efek sedatif yang lebih baik dari diazepam sebagai kontrol positif $(+)$, dengan dosis efektif, yakni 96 $\mathrm{mg} / \mathrm{kgBB}$. 
Selain itu, adanya peningkatan onset sedatif dan durasi hipnotik yang ditunjukan pada kelompok P1, P2, dan P3, tentunya berkaitan erat dengan dosis yang diberikan. Peningkatan dosis infusa daun kayu galala berbanding lurus dengan semakin cepatnya onset sedatif dan semakin meningkatnya durasi hipnotik (tidur) mencit. Semakin besar dosis yang diberikan maka semakin besar efek sedatif-hipnotik yang ditimbulkan pada mencit, yang ditandai dengan adanya efek tenang dan semakin menurunnya aktivitas motorik dan respon atau kepekaan mencit terhadap lingkungan sekitar serta menutupnya kelopak mata, bahkan efek tersebut lebih tinggi dibanding kelompok kontrol positif $(+)$, sehingga dapat dikatakan bahwa efek terapinya lebih baik dibandingkan CTM. Dosis efektif ditunjukkan oleh kelompok mencit P3 dengan dosis $0,7 \mathrm{~mL} / \mathrm{ekor}$, dengan rata-rata waktu onset sedatif, yakni 36.00 menit dan rata-rata durasi hipnotik/tidur 17.67 menit.

Sedatif merupakan kelompok psikoleptika yang mana mekanisme kerja obat-obat yang tergolong di dalamnya cenderung sebagai depresan atau menekan sistem saraf pusat (SSP) sehingga mengurangi kepekaan korteks atau sistem saraf pusat yang mengakibatkan aktivitas motorik menjadi menurun dan sekaligus memberikan efek tenang pada pemakai, namun belum termasuk pada kategori tertidur (Ningsih \& Rahma, 2014; Rahmah, 2016; Umar, 2016). Efek terbesar dari obat-obat sedatif adalah hipnotik yaitu kehilangan kesadaran. Peningkatan dosis untuk obat-obat tertentu bisa menaikan efek menjadi hipnotik. Hipnotika merupakan obat penekan SSP yang menyebabkan hilangnya kesadaran atau menurunnya kepekaan terhadap rangsangan dari lingkungan sekitar. Penggunaan obat hipnotik mengakibatkan rasa kantuk dan mempermudah tidur serta mempertahankan tidur yang menyerupai tidur fisiologis (Fitrah, et al., 2018).

Seperti halnya mekanisme kerja obat sedatif-hipnotik, timbulnya efek sedatif-hipnotik pasca pemberian infusa daun kayu galala memiliki keterkaitan dengan meningkatnya aktifitas GABA, yakni sebuah neurotransmiter utama yang bekerja pada sinapsis inhibitoris di dalam otak yang menghambat aktifitas susunan saraf pusat atau SSP (Wyann \& Fougere dalam Amalia, 2009). Senyawa kimia yang memiliki pengaruh agonis, seperti Alkaloid, flavonoid, saponin, dan tanin, bila kontraksi dapat menghasilkan efek maksimum pada reseptor $\mathrm{GABA}_{\mathrm{A}}$ (Afriani, et al,. 2016; Novindriana, et al,. 2013). Pengikatan senyawa-senyawa tersebut pada reseptor $\mathrm{GABA}_{\mathrm{A}}$ di membran pascasinaptik akan menghambat enzim GABA transminase sehingga jumlah GABA menjadi berlebih dalam otak dan menyebabkan perubahan konformasi pada reseptor GABA. Adanya perbedaan komposisi ion dalam cairan intraselular maupun ekstraselular, mengakibatkan sel mengubah potensial membrannya sebagai respon terhadap stimulus yang diterima oleh sel tersebut.

Dalam kondisi sel mengubah potensial membrannya maka membran tersebut lebih permeabel terhadap ion $\mathrm{K}^{+}$yang meninggalkan sel sehingga saluran atau kanal ion klorida (gated ion channel) terbuka dan mengakibatkan banyak ion klorida yang masuk ke dalam sel karena gradien konsentrasinya yang besar. Aliran ion mendorong potensial membran pada tekanan yang lebih negatif dibandingkan potensial istirahatnya dan menyebabkan hiperpolarisasi membran. Kondisi ini akan menghambat proses penghantaran potensial aksinya dan pada akhirnya menyebabkan sel sulit tereksitasi (Alnamer, Alaoui, Bouidida, Benjouad, \& Cherrah, 2012; Hidayati, 2013; Marfu'ah et al,. 2013; Novindriana, et al,. 2013; Afriani, Riyanto, \& Madang, 2016; Rahmah, 2016; Sari, 2018), yang dalam penelitian ini ditandai dengan adanya penurunan aktivitas motorik mencit hingga menurunnya kepekaan terhadap rangsangan dari lingkungan sekitar. Dengan demikian, daun kayu galala dinilai potensial dalam mengatasi masalah gangguan tidur (insomnia), baik dari segi kualitas maupun kuantitas karena mampu mempercepat onset sedatif serta meningkatkan durasi hipnotik. 


\section{SIMPULAN}

Hasil penelitian membuktikan bahwa daun kayu galala (Erythrina lithosperma) memiliki efek sedatif-hipnotik. Seluruh dosis infusa daun kayu galala $(0,3 ; 0,5$; dan $0,7 \mathrm{~mL} / \mathrm{ekor})$ mampu mempercepat onset sedatif serta meningkatkan durasi hipnotik mencit (Mus musculus) bila dibanding dengan kelompok kontrol positif (+) dan dosis yang efektif yakni $0,7 \mathrm{~mL} / \mathrm{ekor}$. Hasil uji statistik One Way ANOVA pun juga menunjukkan bahwa pemberian infusa daun kayu galala pada kelompok mencit perlakuan (P1, P2, P3) memiliki pengaruh yang lebih signifikan dalam mempercepat onset sedatif dan meningkatkan durasi hipnotik bila dibanding dengan kelompok kontrol positif (+). Selain itu, peningkatan rata-rata onset sedatif serta durasi hipnotik mencit berbanding lurus dengan peningkatan dosis infusa daun kayu galala.

\section{REFERENSI}

Afriani, S. R., Riyanto, R., \& Madang, K. (2016). Pengaruh ekstrak daun sirih (Piper bettle Linn.) Terhadap Efek Sedasi Mencit (Mus musculus L.) Dan Sumbangannya Pada Pembelajaran Biologi SMA. Jurnal Pembelajaran Biologi FKIP Unsri, 3(1), 27-34.

Alnamer, R., Alaoui, K., Bouidida, E. H., Benjouad, A., \& Cherrah, Y. (2012). Sedative and hypnotic activities of the methanolic and aqueous extracts of lavandula officinalis from Morocco. Advances in pharmacological sciences, 2012, 1-5.

Amalia, R. (2009). Pengaruh ekstrak pegagan (Centella asiatica (L.) Urban) terhadap efek sedasi pada mencit Balb/C. (Skripsi), Program Pendidikan Sarjana, Fakultas Kedokteran, Universitas Diponegoro, Semarang.

Anggara, R. (2009). Pengaruh ekstrak kangkung darat (Ipomea reptans Poir.) terhadap efek sedasi pada mencit Balb/C. (Skripsi), Program Pendidikan Sarjana, Fakultas Kedokteran, Universitas Diponegoro, Semarang.

Dewi, S. (2009). Pengaruh bahan anestesi minyak cengkeh pada proses pengangkutan terhadap kualitas spermatozoa induk ikan mas koki (Carassius auratus). (Skripsi), Fakultas Perikanan dan IImu Kelautan, Universitas Padjadjaran, Bandung.

Djalil, A. D., Musyarofah, S., Putra, B. S. N., Genatrika, E., \& Astuti, I. Y. (2017). Potensi biji orokorok (Crotalaria juncea L.) sebagai kandidat obat insomnia. Jurnal Pharmascience, 4(1), 110.

Fitrah, M., Syakri, S., \& Harnita, H. (2018). Uji efektivitas infusa sarang semut (Myrmecodia pendens) terhadap efek sedasi pada mencit (Mus muscullus). Jurnal Farmasi UIN Alauddin Makassar, 5(3), 184-192.

Hanrahan, J. R., Chebib, M., \& Johnston, G. A. (2011). Flavonoid modulation of GABAA Receptors. British journal of pharmacology, 163(2), 234-245.

Hidayati, A. (2013). Uji Ekstrak n-Heksan dari daun kratom (Mitragyna speciose Korth.) pada mencit jantan galur Balb/C. (Skripsi), Program Studi Farmasi, Fakultas Kedokteran, Universitas Tanjungpura, Pontianak.

Jannah, M. K. (2009). Pengaruh ekstrak valerian terhadap efek sedasi pada mencit Balb/C. (Skripsi), Program Pendidikan Sarjana, Fakultas Kedokteran, Universitas Diponegoro, Semarang.

Kholidha, A. N., Suherman, I. P. W. P., \& Hartati. (2016). Uji aktivitas ekstrak etanol daun dadap serep (Erythrina lithosperma Miq.) sebagai Antibakteri terhadap Bakteri Salmonella typhi. Medula, 4(1), 281-290.

Kumalawati, N. D. (2012). Coping stress pada penderita insomnia. (Skripsi), Program Studi Sosiologi, Fakultas Dakwah, Institut Agama Islam Negeri Sunan Ampel, Surabaya. 
Marfu'ah, I., Sudarso, S., \& Diniatik, D. (2013). Efek sedasi dari variasi dosis ekstrak etanol daun ubi jalar (Ipomoea batatas L) pada mencit. Pharmacy: Jurnal Farmasi Indonesia, 10(01), 109123.

Maya, N. I. (2008). Pengaruh ekstrak etanol bunga-bunga pagoda (Clerodendrum paniculatum L.) terhadap waktu tidur mencit jantan dengan metode potensiasi narkose. (Skripsi), Program Studi Ilmu Farmasi, Fakultas Farmasi, Universitas Sanata Dharma, Yogyakarta.

Ningsih, S., \& Rahma, N. (2014). Kemampuan efek sedasi infusa umbi rumput teki (Cyperus rotundus L.) pada mencit jantan ras Swiss. Indonesian Journal on Medical Science, 1(2), 6673.

Novindriana, D., Wijianto, B., \& Andrie, M. (2013). Uji efek sedatif ekstrak etanolik daun kratom (Mitragyna Speciosa Korth.) pada mencit jantan galur Balb/C. Jurnal Mahasiswa Farmasi Fakultas Kedokteran Universitas Tanjungpura, 3(1), 1-13.

Nugroho, M. G., Lestari, F., \& Fitrianingsih, S. P. (2016, 15-16 Agustus 2016). Efek sedatif-hipnotik ekstrak etanol daun Afrika (Vernonia amygdalina Delile) dalam mempercepat onset tidur mencit Swiss Webster Jantan. Paper presented at the Prosiding Seminar Penelitian Sivitas Akademika Unisba: Peran Unisba dalam Pemanfaatan Hasil Penelitian untuk Pengembangan dan Penyebarluasan Iptek dan Imtak yang Berkelanjutan di Jawa Barat, Bandung.

Purnomo, L., Darsono, L., \& Santosa, S. (2004). Efektivitas infusa kayu ules (Helicteres isora L) sebagai obat hipnotik sedatif. Maranatha Journal of Medicine and Health, 3(2), 96-110.

Rahadian, D. D. (2009). Pengaruh ekstrak biji pala (Myristica fragrans Houtt) dosis 7,5 mg/25grBB terhadap waktu induksi tidur dan lama waktu tidur mencit Balb/C yang diinduksi Thiopental. (Skripsi), Program Pendidikan Sarjana, Fakultas Kedokteran, Universitas Diponegoro, Semarang.

Rahmah, A. R. (2016). Uji efek sedatif ekstrak daun gynura procumbens (Lour.) Merr dengan ekstraksi bertingkat terhadap mencit jantan galur Balb/C. (Skripsi), Jurusan Farmakognosi dan Fitokimia, Fakultas Farmasi, Universitas Airlangga, Surabaya.

Rahman, A. A., Firmansyah, R., \& Setyabudi, L. (2018). Aktivitas antibakteri ekstrak etanol daun dadap serep (Erythrina lithosperma Miq.) terhadap pertumbuhan escherichia coli. PHARMACOSCRIPT, 1(1), 1-6.

Revisika. (2011). Efektifitas daun dadap serep (Erythirna subumbrans (Hask) Merr) sebagai penyembuh luka pada tikus putih (Rattus norvegicus Strain Wistar). (Skripsi), Jurusan Biologi, Fakultas Matematika dan IImu Pengetahuan Alam, Universitas Muhammadiyah Malang, Malang.

Sari, D. A. P. (2018). Uji efek hipnotik-sedatif ekstrak etanol 70\% batang jaka tuwa (Scoparia dulcis Linn) terhadap mencit jantan galur Swiss Webster. (Skripsi), Jurusan Pendidikan Dokter, Fakultas Kedokteran, Universitas Muhammadiyah Surakarta, Surakarta.

Sutiawan, M. (2009). Hubungan antara insomnia dengan hipertensi pada kelompok olahraga usia produktif kampus 2 UIN Syarif Hidayatullah Jakarta 2009. (Skripsi), Fakultas Kedokteran dan IImu Kesehatan, UIN Syarif Hidayatullah Jakarta, Jakarta. 
Takahashi, R. N., de Lima, T. C., \& Morato, G. S. (1986). Pharmacological actions of tannic acid; II. Evaluation of CNS activity in animals. Planta medica, 52(04), 272-275.

Umar, A. (2016). Perbandingan efek sedatif acepromazine (ACP) dosis bertingkat pada gambaran elektrokardiogram (EKG) kucing domestik di Makassar. (Skripsi), Program Studi Kedokteran Hewan, Fakultas Kedokteran, Universitas Hasanuddin, Makassar. 